\title{
APPROXIMATION TO THE USE OF HALF-TIMBERED WALLS WITH EARTH INFILL IN SPANISH TRADITIONAL ARCHITECTURE
}

\author{
A. Hueto Escobar ${ }^{1,3, *}$, M. Diodato ${ }^{1,3}$, F. Vegas ${ }^{1,3}$, S. Manzano Fernández ${ }^{2,3}$ \\ ${ }^{1}$ Department of Architectural Composition, Universitat Politècnica de València, Camino de Vera s/n, 46022, \\ Valencia, Spain - (alhuees, madio)@upv.es, fvegas@cpa.upv.es \\ ${ }^{2}$ Architect, Master in Preservation of Architectural Heritage, Universitat Politècnica de València, Camino de Vera s/n, 46022 , \\ Valencia, Spain - sermanfe@ arq.upv.es \\ ${ }^{3}$ Research Centre PEGASO, Universitat Politècnica de València, Valencia, Spain
}

\section{Commission II - WG II/8}

KEY WORDS: Half-timber, Earth-infill, Constructive techniques, Traditional architecture, Spain, Constructive knowledge

\begin{abstract}
:
The term "half-timbered walls with earth infill" refers to a wide number of techniques in which structural wooden elements are combined with enclosures made of earth. The use of these constructive systems dates back to prehistoric times and their evolution has differed based on the physical, social and cultural conditions of each place. Therefore, the objective of this paper is to define the concept of half-timbered walls with earth infill in the Spanish context and to understand the geographical, urban, architectural and constructive reasons that have favoured or hindered its use in traditional architecture. The methodology used is based on the quantitative and qualitative analysis of the largest possible number of case studies. This allows a database to be set up for the purposes of performing global analysis and drawing objective and statistically valid conclusions. This information is managed using a study sheet with information ranging from general aspects of buildings with the presence of these techniques to detailed features of halftimbered walls. The data and conclusions presented in this paper focus on these half-timbered walls, including information on the geographical distribution of these techniques, the characteristics of the buildings in which they are used, the combination of mixed walls with other construction techniques, and the state of conservation and transformation of the buildings in which they are used. It has been established that these techniques are common in mountainous landscapes, where there is optimal woodland for construction, and in urban environments, where they are presented as optimum techniques to maximize the profitability of the buildable surface.
\end{abstract}

\section{INTRODUCTION}

The term "mixed techniques" refers to a large number of constructive solutions where various materials, whether natural or industrialized, are combined with a clear functional and mechanical specialization of the elements. In architecture, halftimber refers to the combination of wooden elements with structural function and other filling elements used for enclosure, insulation and protection (De Hoz Onrubia et al., 2003). Mixed techniques combining earth and wood can be used to configure different types of construction elements of varying complexity. In the specific case of walls, in addition to being used as mere partitions they can be load-bearing walls which completely configure the structure of a building. Over centuries a wide range of solutions has been developed, with different styles, geometries, materials, constructive connections with other elements, etc. The first writing reference to half-timbered walls was offered by Vitruvius, who described the opus craticium as an orthogonal framework of timber filled with bricks, cement or rough stones. However, its origin as a group of constructive techniques dates back to the first shelters built by humans. Its development has been notable in seismic areas, with paradigmatic systems such as pombalino wall in Portugal or baraccata house in Italy (Poletti et al., 2015; Dipasquale et al., 2015). However, the geographical expansion of these techniques extends to other countries without relevant seismic activity, including Germany (fachwerk), France (colombage), the United Kingdom (half-timbered houses), Spain (entramados), Romania, Greece, and Finland. (Copani, 2007; Langenbach, 2017; Dutu et al., 2012; Gónzalez-Redondo, 2014).
Its widespread use is due to the local availability of material, as no complicated transformations or highly specialized workforces are required. Structurally, it requires less thickness than other massive techniques, while its flexibility ensures better performance in weaker soils or seismic areas. Furthermore, rubble from other buildings can be used, as can wooden elements with small defects, and damaged elements can be easily replaced. In contrast, the fact that they are constituted by wood means that it is more vulnerable than other techniques built entirely with earth, especially to fire and degradation caused by xylophagous insects (GónzalezRedondo, 2014). Despite the numerous variants found in Spain (Figure 1), a first classification could be established depending on the structural importance of the wood and the constructive logic used in the filling (De Hoz Onrubia et al., 2003).

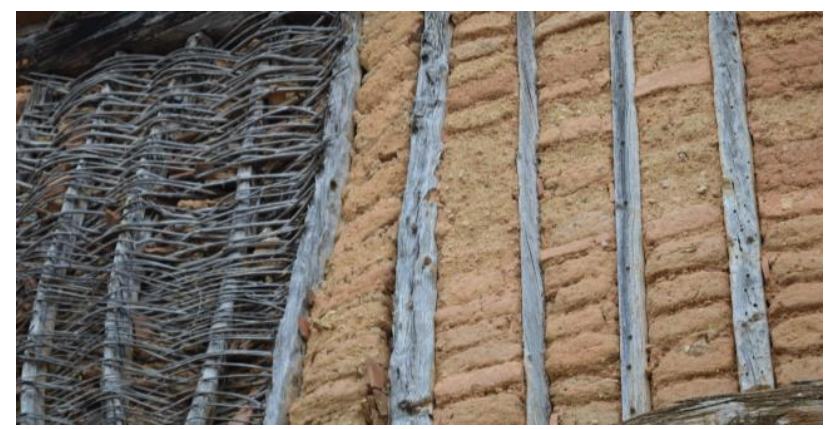

Figure 1. Half-timbered wall with wattle-and-daub (light interwoven fibres) and adobe filling (heavy masonry pieces).

\footnotetext{
* Corresponding author
} 
On the one hand, muros entramados where the wood assumes almost all the structural function and the spaces between the framework can be filled using monolithic or masonry techniques.

On the other hand, muros tejidos where the spaces are completed with screens or light enclosures of interwoven vegetable fibres, such as wattle-and-daub or lath and plaster techniques.

\section{OBJECTIVES AND METHODOLOGY}

The evolution of these constructive systems of prehistoric origin has differed depending on the physical, social and cultural conditions of each individual place. Therefore, the main objective of this paper is to define the concept of half-timber walls in the case of Spain. To do so, it is necessary to understand the geographical, urban, architectural and constructive reasons which promote or hinder its use in Spanish traditional architecture.

This article is part of a major investigation, aiming to carry out a global analysis of the mixed walls of earth and wood in the Spanish territory. This analysis seeks to define and classify the different types of walls built in traditional Spanish architecture using mixed techniques, and also to understand their constructive logic and study the common characteristics and differentiating features.

The methodology used is based on the quantitative and qualitative analysis of the largest possible number of case studies. The research derives from an extensive collaborative database of traditional earthen architecture in the Iberian Peninsula. In this database, more than 1,200 buildings with monolithic walls, masonry walls, mixed walls or earth renderings were documented and photographed, in 1,013 different locations (Mileto et al., 2018).

The buildings in the database were then filtered in order to identify only those with half-timbered walls and enough information to constitute valid case studies. The final analysed sample consisted of 217 buildings with the presence of these techniques, distributed throughout 83 different locations (Figure 2).

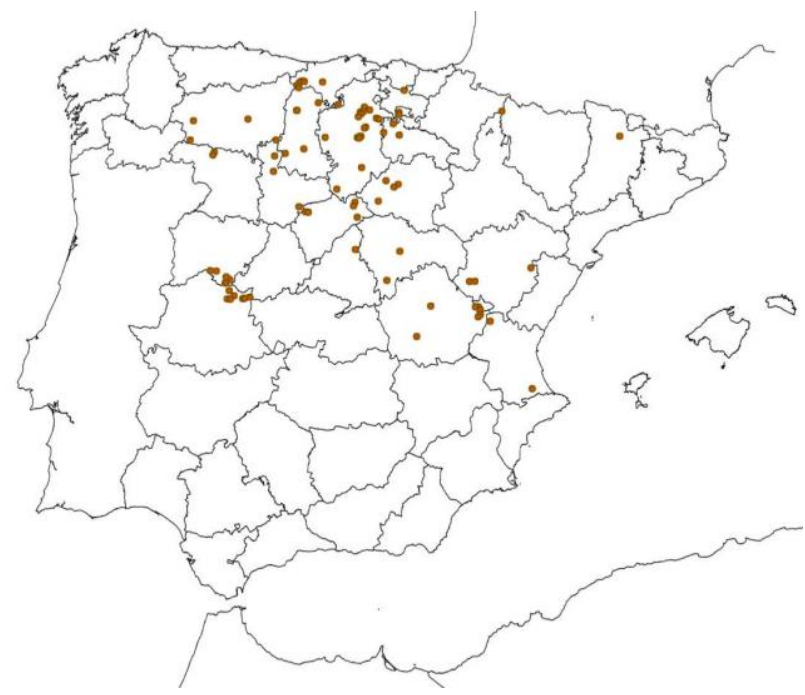

Figure 2. Geographical distribution of the 83 sites where earth and wood mixed walls have been located.
A study sheet is proposed for the scientific and objective study of a large number of cases. This study sheet has been structured into two large blocks: general data about the studied building and extremely detailed technical aspects of the wall built with mixed techniques. Using the information collected, a database was set up to perform a global analysis and to draw objective, statistically valid conclusions.

The first block of the study sheet (Figure 3 ) specifically collects aspects and information which are easily obtainable from all case studies. The analysis of this general information leads to the conclusions presented here on the context in which half-timbered walls are used in traditional Spanish architecture. These conclusions focus on the geographical distribution of this type of walls, the characteristics of the buildings in which they are used, the combination of mixed techniques with other construction techniques, and an examination of the state of conservation and transformation of the buildings where they are used.

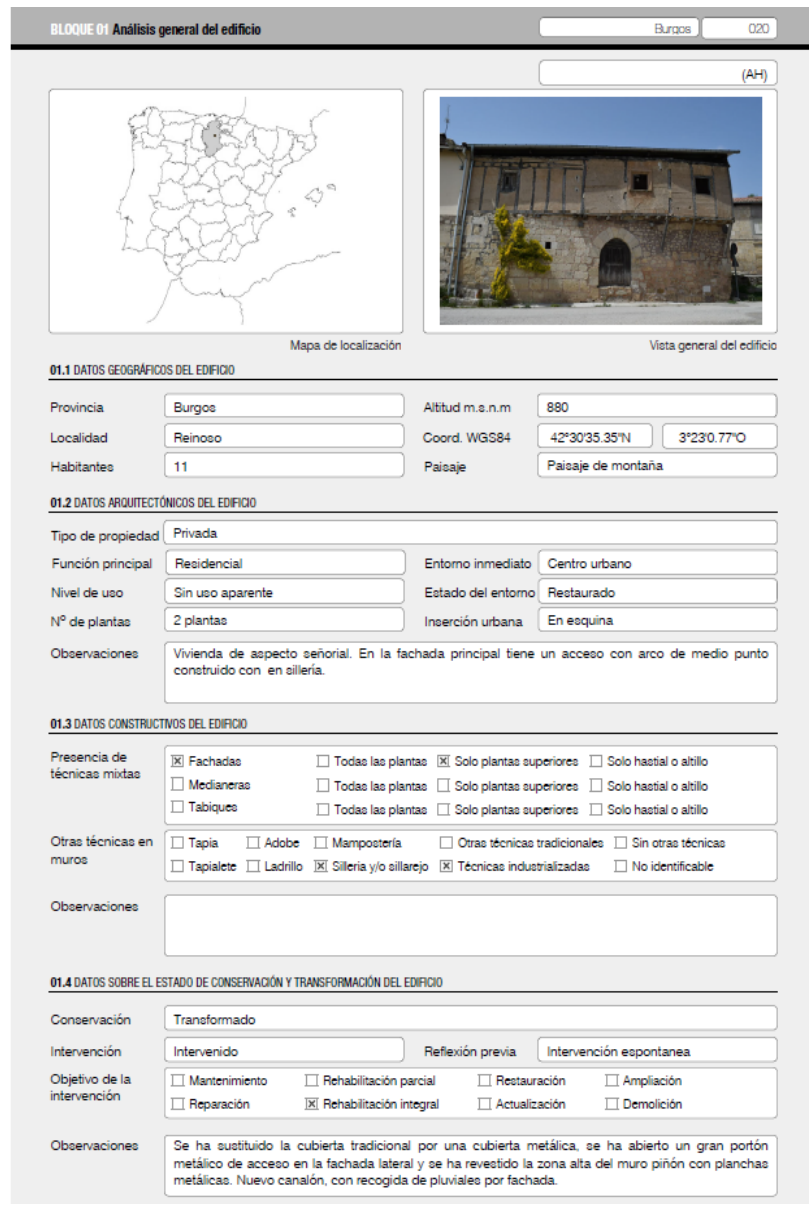

Figure 3. First part of the proposed study sheet, with general data about the building. Example located in Reinoso (Burgos).

However, the factors which have limited the development of this investigation should be considered. On the one hand, there is a geographical limitation because it is impossible to visit each and every one of the Spanish localities to verify the existence or absence of these techniques. On the other hand, visual analysis has been carried out mostly from the outside. This means that the conclusions refer mostly to visible facades and party-walls. The use of these techniques in interior partitions could not be observed, although bibliographical information suggests that it was a very common practice. 


\section{TERRITORIAL ANALYSIS}

\subsection{Geographical distribution}

Buildings with half-timbered walls have been located mostly in the northwestern part of the country, including the entire autonomous community of Castilla y León and surrounding provinces such as Álava, La Rioja, Guadalajara and Cáceres. Although their presence is more conspicuous in the northwest area where wood is abundant, a review of the literature shows that they were also used to build the historic centres of many cities, including Madrid (Gónzalez-Redondo, 2014).

Geographical distribution should be analysed from the perspective of the filling, a choice derived mainly from the local availability of materials and knowledge. However, this decision is also conditioned by other specific factors, including the importance of the building, the function for which it is intended, and the economic status of the owners.

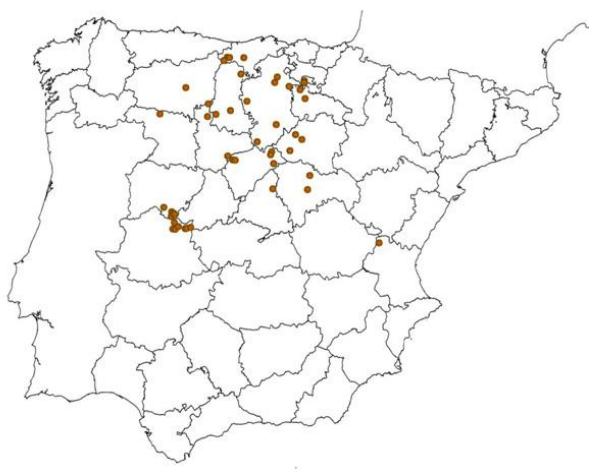

Figure 4. Geographical distribution of analysed half-timbered walls with masonry infills.

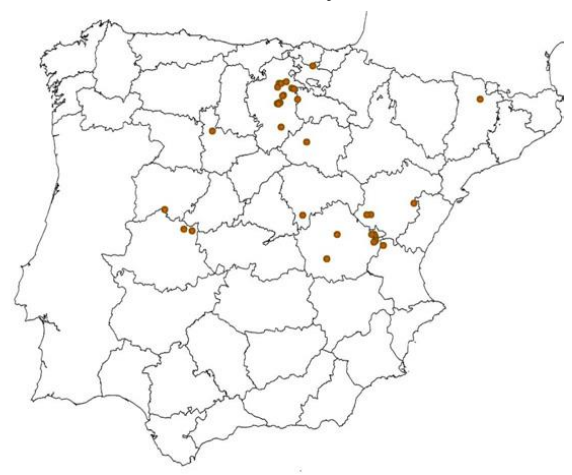

Figure 5. Geographical distribution of analysed half-timbered walls with monolithic infills.

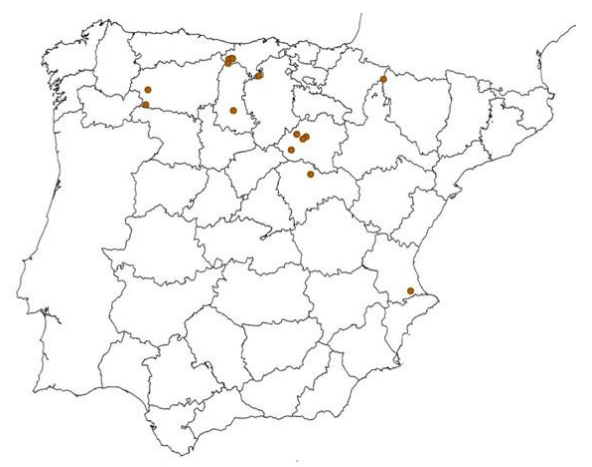

Figure 6. Geographical distribution of analysed half-timbered walls with light enclosures.
The masonry fillings, composed mainly of adobe, are homogeneously distributed throughout almost all the territory analysed (Figure 4).

In contrast, monolithic fillings based on poured or stacked earth are concentrated in certain areas of Spain (Figure 5). For example, poured earth filling is mainly found near Burgos, while fillings of stone slabs with formwork on one side have only been located in areas of Cuenca and Teruel.

In the case of rigid screens or interwoven vegetable fibres enclosures, these walls are mainly concentrated in the north of Castilla y León and the Cantabrian coast (Figure 6).

\subsection{Population}

These constructive techniques can generally be observed in towns with small populations (Table 1). In fact, $67 \%$ of the localities have a population of less than 500 inhabitants and almost a third of the sample has a population of less than 100 inhabitants.

\begin{tabular}{lcccc}
$<100$ inhab. & 26 & $31 \%$ & \multirow{2}{*}{$67 \%$} \\
\cline { 1 - 3 } $100-500$ inhab. & 30 & $36 \%$ & \\
\hline $500-1000$ inhab. & 8 & $10 \%$ & \\
\cline { 1 - 3 } $1000-5000$ inhab. & 13 & $16 \%$ & $25 \%$ \\
\hline$>5000$ inhab. & 6 & $7 \%$ & $7 \%$ \\
\hline Total & 83 & &
\end{tabular}

Table 1. Population ranges.

This can be correlated to the high risk of depopulation and abandonment of the rural areas of Spain. In recent decades, the rural exodus to the big cities has been exacerbated by the absence or poor condition of transport networks, difficult access to quality basic services, or the precariousness of the labour market.

In this regard, it should be noted that some of the buildings studied are used as second homes for summer use and that some towns, such as Calatañazor (Soria), Santo Domingo de Silos (Burgos) and the villages located along Valle del Jerte (Cáceres), survive thanks to thriving rural tourism.

Despite the lack of maintenance and the consequent risk of loss of material heritage, depopulation has favoured interventions or transformations of traditional buildings to a lesser extent. As a result, their original characteristics remain more or less intact and these buildings could be considered a direct source of information on traditional construction techniques.

However, the fact that only $7 \%$ of the sample analysed corresponds to municipalities with more than 5000 inhabitants does not directly imply the absence of half-timbered walls.

In locations with a larger population there is a high likelihood that despite buildings being renovated more often there are still examples, mostly hidden in party-walls or under all kind of renderings or claddings.

This is due partly to the high building density hiding most of the party-walls, but also to the maintenance standards established by urban regulations and aesthetic decorum. 


\subsection{Altitude, climate and landscape}

Another determining geographical factor is altitude, which is directly related to the weather and the possible presence of optimal woodland masses for construction. The expansion to other geographical areas was traditionally conditioned by the ability to import wood (Moreno Dopazo, 2014), into areas with the presence of river channels allowing the wood trade or into large urban centres with high purchasing power.

$89 \%$ of the municipalities studied (Table 2) are at an altitude above 500 masl, in some cases even reaching 1200 masl.

\begin{tabular}{|c|c|c|c|}
\hline$<100$ masl & 0 & $0 \%$ & $0 \%$ \\
\hline 100-200masl & 0 & $0 \%$ & \multirow{4}{*}{$11 \%$} \\
\hline 200-300 masl & 1 & $1 \%$ & \\
\hline $300-400$ masl & 2 & $2 \%$ & \\
\hline $400-500$ masl & 6 & $7 \%$ & \\
\hline $500-600$ masl & 11 & $13 \%$ & \multirow{5}{*}{$72 \%$} \\
\hline $600-700$ masl & 8 & $10 \%$ & \\
\hline $700-800$ masl & 20 & $24 \%$ & \\
\hline 800-900 masl & 9 & $11 \%$ & \\
\hline 900-1000 masl & 12 & $14 \%$ & \\
\hline $1000-1100$ masl & 8 & $10 \%$ & \multirow{3}{*}{$17 \%$} \\
\hline $1100-1200$ masl & 5 & $6 \%$ & \\
\hline$>1200$ masl & 1 & $1 \%$ & \\
\hline Total & 83 & & \\
\hline
\end{tabular}

Table 2. Altitude ranges.

The classification proposed by the National Geographic Institute has been followed in the study of the landscape environment of these municipalities. It classifies the Spanish landscapes into mountains, stops and plains, peneplains and meadows, riverbanks, coastal areas, metropolitan areas and insular areas.

In the sample, $60 \%$ of the locations studied are in mountainous areas and $32 \%$ in moors and plains, indicating the importance of the proximity of wooded areas (Table 3 ). The remaining $8 \%$ are located near riverbanks, confirming that the possibility of river trade of wood was a determining factor for the expansion of this type of construction techniques.

No cases have been located in coastal, island or metropolitan areas. In the case of the first two, this absence is probably due to the lack of wood in these areas and the vulnerability of these techniques to humidity. In the last case, as already stated earlier, any half-timbered walls remaining are probably hidden.

\begin{tabular}{lccc} 
Mountains & 50 & $60 \%$ & $60 \%$ \\
\cline { 1 - 3 } Stops and plains & 22 & $27 \%$ & \multirow{2}{*}{$32 \%$} \\
\cline { 1 - 3 } Peneplains and meadows & 4 & $5 \%$ & \\
\cline { 1 - 2 } Riverbanks & 7 & $8 \%$ & $8 \%$ \\
\cline { 1 - 2 } Total & 83 & &
\end{tabular}

Table 3. Landscape typologies.

\section{ARCHITECTURAL ANALYSIS}

In addition to the geographical factors previously studied, other specific circumstances condition the building design and the construction techniques used. The architectural analysis includes aspects such as the function for which it is intended, the environment closest to its location, the architectural typology, and the number of storeys built.

At the same time, other hard-to-quantify social factors, such as the needs, specific tastes, and spending power of the owners, should be added. However, often it is not possible to establish these aspects, because these traditional buildings were built centuries ago and have been modified various times by different owners.

\subsection{Function and environment}

The study of the function and the environment closest to the buildings studied helps identify the functional needs of the owners and the physical conditions that influenced the design and typology of the building.

Firstly, it should be noted that $70 \%$ of the sample of buildings studied are dedicated to residential use, while the rest is used for other functions related to labour and production (Table 4). Secondly, $96 \%$ of the cases studied are located in an urban environment, either the centre of the town or village itself or in the nearest periphery. When studying the function and the environment together, residential use is more common in the urban centre while the proportion of uses related to the workplace increases in peripheral or rural areas.

\begin{tabular}{lcc} 
Residential use & 152 & $70 \%$ \\
Agricultural use & 42 & $19 \%$ \\
Other uses & 11 & $5 \%$ \\
Productive uses & 9 & $4 \%$ \\
Mixed uses & 3 & $1 \%$ \\
\hline Total & 217
\end{tabular}

Table 4. Main function or use.

\subsection{Architectural typologies and number of storeys}

As already mentioned, the use and the environment in which they are built condition the choice of certain architectural typologies and the number of floors to be built. The most common architectural typologies (Table 5) are buildings between party walls or on corners, accounting for $84 \%$ of the sample of buildings analysed. As in the previous case, if the typology and the environment are studied together, it can be observed that in urban environments the most common typology is between party walls or on corners, while the percentage of detached buildings increases in the periphery and rural areas.

\begin{tabular}{lcc} 
Row buildings & 105 & $48 \%$ \\
Corner buildings & 79 & $36 \%$ \\
Detached building & 33 & $15 \%$ \\
\hline Total & 217 &
\end{tabular}

Table 5. Architectural typologies. 
In the case of the number of floors of the buildings studied (Table 6), these tend to be between two and three storeys high.

The distribution of the number of floors depends on the setting. The number of storeys increases considerably in urban areas, reaching up to 4 in some cases. Specifically, the average heights of the buildings studied in urban environments are 2.44 floors, 2.18 in peripheral areas and 2.00 in rural areas.

In this regard, it is important to remember that these techniques are usually used on baseboards or ground floors made with more resistant materials such as rubble masonry or ashlar masonry.

\begin{tabular}{lcc} 
1-storey building & 10 & $5 \%$ \\
2-storey building & 120 & $55 \%$ \\
3-storey building & 82 & $38 \%$ \\
4-storey building & 5 & $2 \%$ \\
\hline Total & 217 \\
\hline & Table 6. Number of storeys.
\end{tabular}

\section{CONSTRUCTIVE ANALYSIS}

Finally, it is essential to analyse the areas of the building where half-timbered walls are used, as well as the correlation with other construction techniques.

As for the areas, half-timber walls have been identified in facades in 186 of the 217 cases, because this is the most visible area of the building from the outside. The identification in party walls and partitions has been conditioned by visual analysis from the outside. However, half-timbered walls have been identified in 52 party walls and 5 interior partitions. Detection of mixed techniques in party-walls has only been possible when there was a height difference between buildings. In the case of interior partitions, it has only been possible when the main walls were partially collapsed.

As already mentioned, half-timbered walls are susceptible to moisture and are therefore often used above walls built with more durable techniques (Table 7). It has only been possible to confirm that all exterior and visible walls were constructed with half-timbered techniques in $2 \%$ of cases.

Above all, half-timbered walls are combined with other techniques that involve the use of stone, appearing in $78 \%$ of buildings. Masonry is used in $31 \%$ of the cases, mostly isolated, although sometimes it appears combined with other traditional techniques. On other occasions, the masonry walls are presented with reinforcements of ashlar masonry in corners and jambs, specifically in $25 \%$ of the cases studied. The presence of ashlar masonry configuring a whole wall has been found in only $7 \%$ of the cases, as its use was probably limited due to the laborious and expensive process of transformation of the stone.

The isolated presence of other techniques such as brick, adobe, rammed earth or sod is much less common. It is only found in $3 \%$ of the studied sample. In the case of brick, this may be a consequence of its high production cost. In the case of earthen techniques, it might be because they are more susceptible to moisture and other more durable materials are preferable.

\begin{tabular}{|c|c|c|c|}
\hline Rubble masonry & 62 & $29 \%$ & \multirow{3}{*}{$41 \%$} \\
\hline $\begin{array}{r}\text { Combined with } \\
\text { other traditional techniques }\end{array}$ & 23 & $11 \%$ & \\
\hline $\begin{array}{r}\text { Combined with } \\
\text { industrial techniques }\end{array}$ & 3 & $1 \%$ & \\
\hline $\begin{array}{l}\text { Rubble masonry } \\
\text { with ashlar reinforcements }\end{array}$ & 55 & $25 \%$ & \multirow{3}{*}{$30 \%$} \\
\hline $\begin{array}{l}\text { Combined with other } \\
\text { traditional techniques }\end{array}$ & 7 & $3 \%$ & \\
\hline $\begin{array}{l}\text { Combined with } \\
\text { industrial techniques }\end{array}$ & 5 & $2 \%$ & \\
\hline Ashlar masonry & 12 & $6 \%$ & \multirow{3}{*}{$7 \%$} \\
\hline $\begin{array}{l}\text { Combined with other } \\
\text { traditional techniques }\end{array}$ & 0 & $0 \%$ & \\
\hline $\begin{array}{r}\text { Combined with } \\
\text { industrial techniques }\end{array}$ & 2 & $1 \%$ & \\
\hline
\end{tabular}

Traditional techniques

\begin{tabular}{|c|c|c|c|c|}
\hline & Brick masonry & 3 & $1 \%$ & \multirow{4}{*}{$5 \%$} \\
\hline & Adobe & 5 & $2 \%$ & \\
\hline \multicolumn{2}{|r|}{ Rammed earth } & 1 & $0 \%$ & \\
\hline & Sod & 1 & $0 \%$ & \\
\hline Industrial technique & & 5 & $2 \%$ & $2 \%$ \\
\hline Only half-timber & & 5 & $2 \%$ & $2 \%$ \\
\hline Not recognisable & & 28 & $13 \%$ & $13 \%$ \\
\hline Total & & 217 & & \\
\hline
\end{tabular}

Table 7. Presence of other building techniques in the walls of the buildings analysed.

\section{GENERAL STATE OF CONSERVATION AND TRANSFORMATION DYNAMICS}

Analysing the general conservation status of the 217 buildings where half-timbered walls have been located is the first step to understanding the effect of the degradation process of both the building and the half-timbered walls.

Only $26 \%$ of the buildings studied can be considered well preserved with maintenance interventions that respect their original characteristics. The same amount could be considered maintained, although the abandonment of the last decades is favouring the development of new degradation processes.

In contrast, $19 \%$ of the studied buildings have a high degree of degradation or are in a ruinous state. Unfortunately, the most common state of conservation is refurbished, which reaches $29 \%$ of the sample studied. This condition implies that they have been altered without complying with material or structural compatibility. Therefore, it covers a wide range of solutions based on the needs, tastes and economic capacity of the owners. 
It is necessary to remember that interventions in traditional architecture are often carried out as an immediate response to a problem or need, without establishing any criteria or developing previous studies (Mileto et al., 2018). They respond more to individual needs, capacities and tastes than to the intervention criteria commonly applied in restoration.

In general terms, $83 \%$ of the buildings have been intervened to a lesser or greater extent (Table 8) while 68\% of these transformed buildings have been spontaneously intervened (Table 9).

\begin{tabular}{lcc} 
Without any kind of intervention & 37 & $17 \%$ \\
\hline With interventions & 180 & $83 \%$ \\
\hline Total & 217 &
\end{tabular}

Table 8. State of intervention of studied buildings.

\begin{tabular}{lcc} 
Premeditated intervention & 57 & $32 \%$ \\
\hline Spontaneous intervention & 123 & $68 \%$ \\
\hline Total & 180 &
\end{tabular}

Table 9. Type of previous consideration of transformed buildings.

Therefore, for the study of transformation dynamics, these should be classified according to their main objective. It should also be considered that within a single building several interventions can appear with different objectives or that the same intervention can respond simultaneously to several objectives (Figure 7).

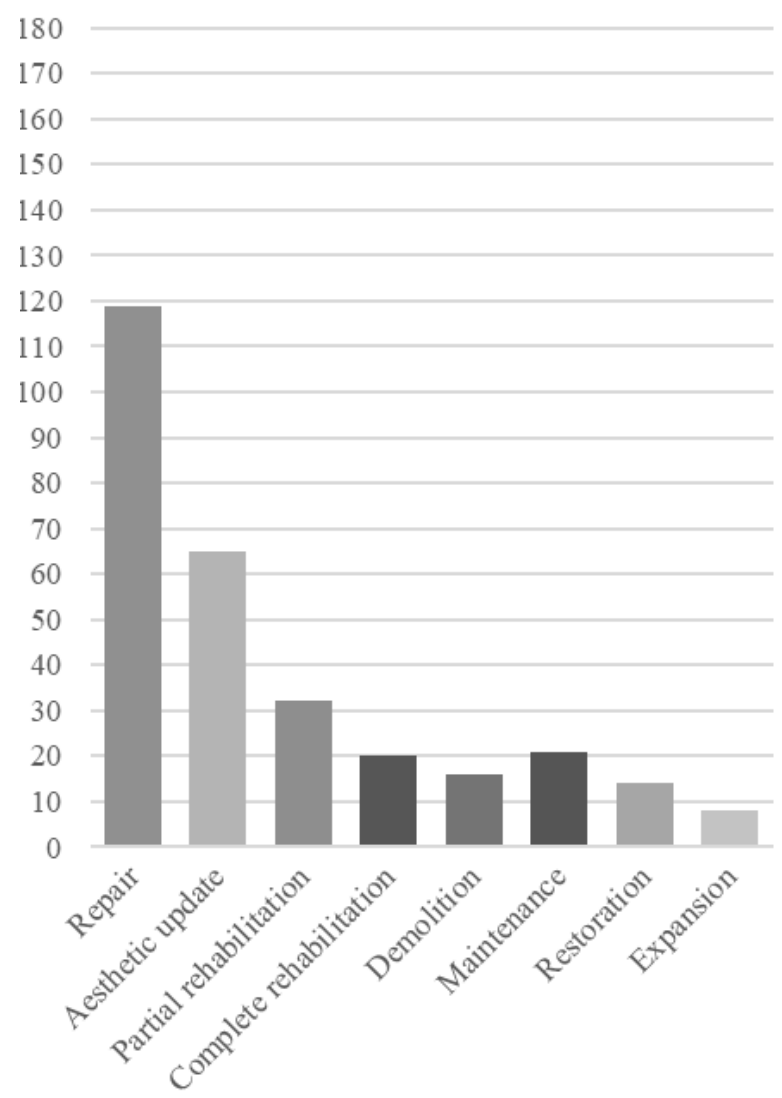

Figure 7. Type of interventions in transformed buildings.
Repair interventions are the most common, being found in 119 cases of the 180 buildings intervened. Together with the partial rehabilitation interventions, present in 32 cases of the 180 studied, they entail less impact than other interventions, mainly because they repair specific areas or elements that present damages or because they rehabilitate specific areas of the building to adapt them to current standards.

Repairs mostly involve the use of industrial materials, probably for economic reasons or near availability. One example worth mentioning is the partial or total replacement of the original adobe infill with an industrial brick infill (Figure 8). Also, the widespread use of cement mortar to patch some areas of the masonry or to coat entire facades has favoured the appearance of humidity and associated degradation processes.

The most common partial rehabilitation is the replacement of window frames and the installation of blinds (Figure 9). The installation of electrical wiring nailed to the wooden elements.is also common. But the most important one involves the modification of the framework to allow access for large vehicles, related to a change of their original use to new use as a garage (Figure 10)

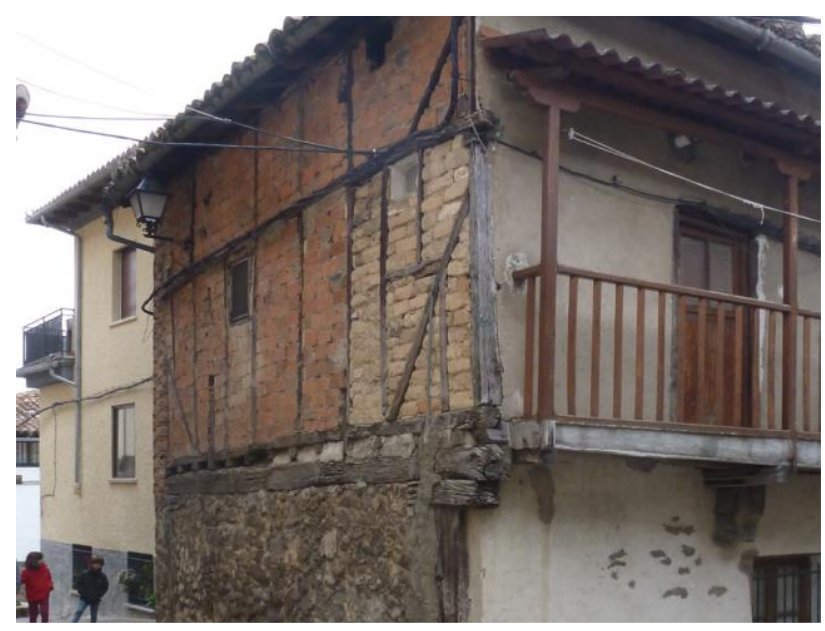

Figure 8. Building in Garganta la Olla (Cáceres), in which adobe infill has been substituted with industrial bricks.

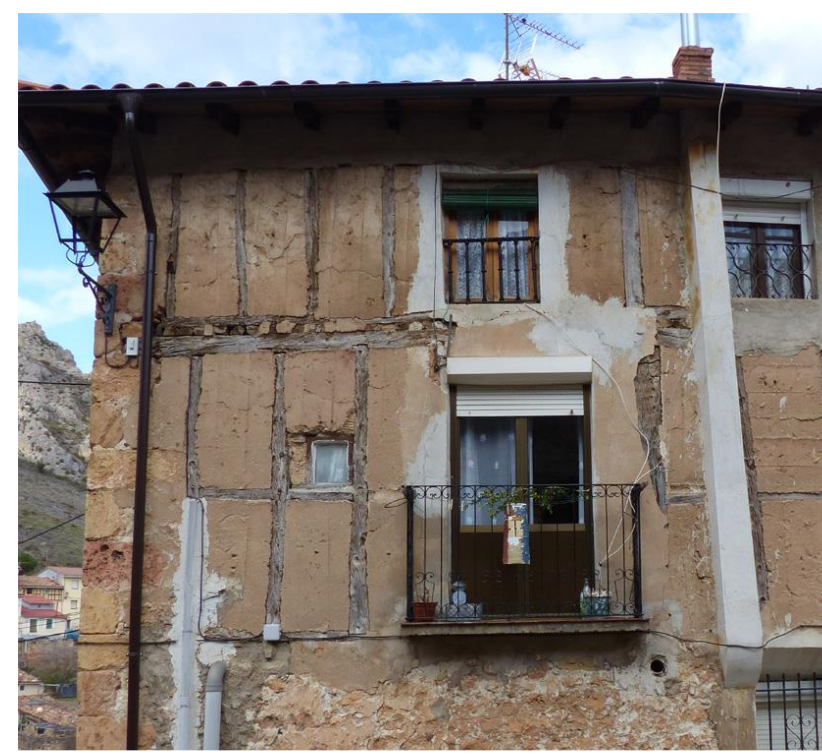

Figure 9. Building in Poza de la Sal (Burgos), partially rehabilitated with new windows. 
In contrast, larger interventions are less common. Complete rehabilitations are present in 20 of the 180 cases of transformed buildings and expansion in 8 cases. The few expansions detected correspond to increases in height, usually with raised industrial brick walls (Figure 10). The aesthetic updates, found in 65 of the 180 cases studied, correspond mainly to transformations of the main facade and new cement mortar coatings (Figure 11).

The less common interventions are precisely those that involve previous consideration and a willingness to preserve the preexisting element. Maintenance interventions in particular are present in 21 cases and restoration in 14 cases of the 180 studied. This may be due to the lack of valorisation of the vernacular heritage, but also to the expansion of industrial materials and the loss of knowledge concerning traditional techniques.

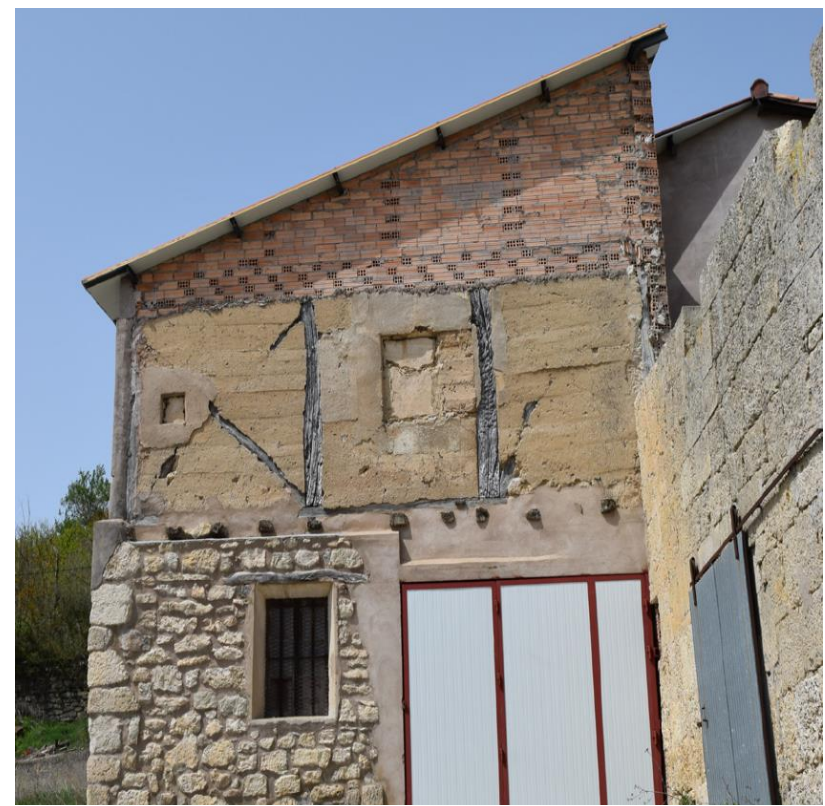

Figure 10. Building in Reinoso (Burgos), extended with brick walls and rehabilitated as a garage.

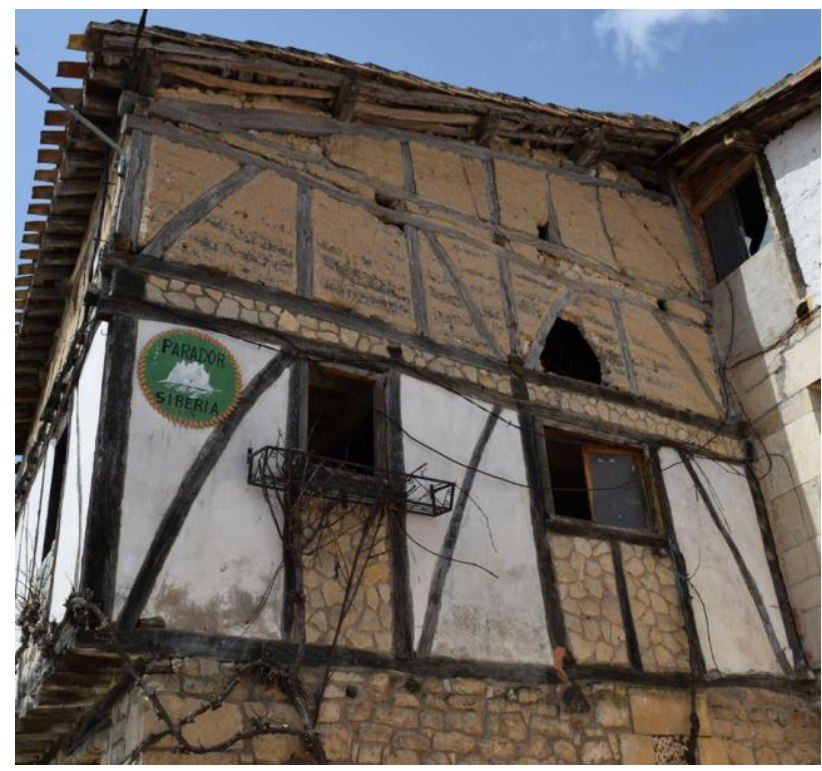

Figure 11. Building in Valdazo (Burgos), aesthetically updated with mortar rendering.

\section{CONCLUSIONS}

The territorial analysis of the municipalities where these types of techniques have been detected confirms that they are typical of mountain areas. These areas are located at a certain height above sea level in climates that favour the optimal growth of trees for construction.

The architectural analysis shows the more widespread use of these techniques in urban environments, where they are used to build residential buildings with some height development and forming part of crowded blocks. The less common use in peripheral or rural areas does not respond to the same logic of land occupation. In these areas, they are mostly individual lower buildings for agriculture or production.

This is because half-timbered walls are a constructive technique which tends to maximize the profitability of buildable surface in urban environments. On the one hand, they could be built higher and were not as thick as other massive earth techniques. On the other hand, cantilevers could be used to increase interior space. This is possible because the wooden pillars go from one floor to the next, and the beams can be prolonged.

The constructive analysis has confirmed that in most cases halftimbered walls are combined with more durable techniques, such as rubble masonry or ashlar masonry. The half-timbered walls are usually used to build the upper floors, due to their vulnerability to soil humidity.

In terms of the general state of conservation, half of the sample studied can be considered to be in good condition. However, many of these buildings are beginning to show slight degradation processes which, if left untreated, could lead to considerable damage.

The other half of the sample is in a poor state of conservation, ranging from dilapidation or collapse to refurbishment, which covers a wide range of solutions based on the needs, tastes and spending power of the owners.

The transformation dynamics detected are mainly repairs and refurbishments of specific areas or elements, mostly with industrial materials and techniques. Larger interventions, such as expansion or complete rehabilitations, are less common for economic reasons. Finally, the least common interventions are those involving some prior consideration and willingness to maintain the pre-existing elements and their heritage value.

These conclusions have made it possible to understand the geographical, architectural and constructive context in which these techniques are used. It has also been possible to develop an initial approach to the state of conservation and the dynamics of transformation affecting this type of vernacular heritage.

To fully understand this type of construction technique, the investigation will continue to analyse in detail issues such as construction typologies, types of geometry, different filling materials, and joints between the framed walls and other construction elements.

The degradation processes and the interventions carried out in half-timbered walls specifically should also be examined to propose guidelines for their restoration and enhancement as vernacular heritage. 


\section{ACKNOWLEDGEMENTS}

This study is part of the research project "La arquitectura de tierra en la Península Ibérica: Estudio de los riesgos naturales, sociales y antrópicos y estrategias de intervención e incremento de la resiliencia" Risk-Terra (ref. RTI2018095302-B-I00; main researchers: Camilla Mileto y Fernando Vegas), funded by the Spanish Ministry of Science, Innovation and University.

The identification and location of many case studies has been possible thanks to the earlier research project "La restauración $y$ rehabilitación de arquitectura tradicional de tierra en la Península Ibérica. Líneas guía y herramientas para una intervención sostenible" SOStierra (ref. BIA 2014-55924- R, main researchers: Camilla Mileto y Fernando Vegas) funded by the Spanish Ministry of Economy and Competitiveness.

The authors wish to thank all the researchers who took part in the process of locating, identifying, and documenting a large number of buildings with earth construction techniques.

This research has been developed within a doctoral thesis funded by the Spanish Ministry of Science, Innovation and University (Ref. FPU18/01596).

\section{REFERENCES}

Copani, P., 2007. Timber.frame buildings in Scandinavia: High deformation prevent the system from collapse. Froma material to structure - Mechanical behavior and failures of timber structures. ICOMOS IWC-XVI International Symposium.

De Hoz Onrubia, J,, Maldonado Ramos, L., Vela Cossío, F., 2003. Diccionario de construcción tradicional con tierra. San Sebastian, Editorial Nerea.

Dispasquale, L., Sidik, D.O., Mecca, S., 2015. Locale seismic cultural and traditional earthquake-resistant devices: The case study of Casa Baraccata. Vernacular Architecture: Towards a Sustainable Future, 255-260. Londres, CRC Press, Taylor \& Francis Group.

Dutu, A., Ferreira, J.G., Guerreiro, L., Branco, F.E., Gonçalvez, A.M., 2012. Mampostería con madera sismorresistente en Europa. Materiales de construcción, 62(308), 615-628.

Gónzalez-Redondo, E., 2014. De la construcción entramada a la introducción de las estructuras metálicas en Madrid. Informes de la Construcción, 66(534), e025.

Instituto Geográfico Nacional, 2019. España en mapas. Una síntesis geográfica. Madrid, Centro Nacional de Información Geográfica.

Langenbach, R., 2017. Timber 2.0: Resilience and Vulnerability of Wood Construction in Earthquakes and Fires. Proceedings of SHATIS'17: $4^{\text {th }}$ International Conference on Structural Health Assessment of Timber Structures.

Mileto, C., Vegas, F., Cristini, V., García-Soriano, L., 2018. SOSTierra Project. Initial results. Vernacular and Earthen Architecture. Conservation and Sustainability, 185-190. Londres, CRC Press, Taylor \& Francis Group.
Moreno Dopazo, A., 2014. Una arquitectura en el territorio. Naturaleza de los tipos de la edificación vernácula española: La casa tradicional soriana. Doctoral Thesis, Universitat Politècnica de València.

Poletti, E., Vasconcelos, G., Lourenco, P., 2015. Timber frames as earthquake resisting system in Portugal. Seismic Retrofitting: Learning from Vernacular Architecture, 161-166. Londres, CRC Press, Taylor \& Francis Group. 